\title{
PENGARUH PELATIHAN COACHING TERHADAP KEMAMPUAN PEMECAHAN MASALAH PADA SUPERVISOR
}

\section{THE EFFECTIVENESS OF COACHING TRAINING ON PROBLEM SOLVING ABILITY AMONG SUPERVISORS}

\author{
Dian Dwi Nur Rahmah \\ Arief Fahmie \\ Fakultas Psikologi dan Ilmu Sosial Budaya, Universitas Islam Indonesia, Yogyakarta \\ e-mail: diandwinurrahamah@rocketmail.com
}

\begin{abstract}
This study aims to determine the effectiveness of coaching training in improving problem solving skills of PT.X supervisor in East Kalimantan. The hypothesis is that coaching training could enhance the ability of problem solving of supervisor. Coaching consists of four aspects, there are able to understand the problem, able to seek and assess alternative solutions, able to implement the solution, and able to carry out an evaluation of the solutions that have been implemented. The study involved 26 new supervisors with tenure 1-3 years. Measuring instrument was problem solving scale (Ellis and Hunt, 1993), which had 25 items. Data analysis using independent sample t-test showed a nonsignificance value of $p$ value $(p=$ $0.506>0.05)$ in the post-test, the hypothesis stated are not accepted. Thus, there is no difference in the ability of solving problems in experimental and control groups. However, when the implementation of the follow-up showed a significance value $p$ value $(p=0.030>0.05)$, which indicates that there are differences in post-test to follow up of the experimental group.
\end{abstract}

Keywords: coaching training, problem solving ability

\begin{abstract}
ABSTRAK
Penelitian ini bertujuan untuk mengetahui pengaruh pelatihan coaching terhadap kemampuan pemecahan masalah pada supervisor di PT.X Kalimantan Timur. Hipotesis yang diajukan adalah ada pengaruh pelatihan coaching terhadap kemampuan pemecahan masalah yang terdiri atas empat aspek, yaitu mampu memahami masalah, mampu mencari dan menilai alternatif solusi, mampu melaksanakan solusi, dan mampu melaksanakan evaluasi terhadap solusi yang telah dilaksanakan. Penelitian ini melibatkan 26 supervisor baru dengan masa kerja 1 - 3 tahun. Alat ukur yang digunakan adalah skala pemecahan masalah menurut Ellis dan Hunt (1993) yang berjumlah 25 butir. Analisis hipotesis menggunakan Independent Sample t-test menunjukkan nilai signifikansi $p$ value $(p=0,506>0,05)$. Pada pascates, maka hipotesis dinyatakan tidak diterima. Dengan demikian, tidak ada perbedaan kemampuan pemecahan masalah pada kelompok eksperimen dan kontrol. Walaupun demikian, saat pelaksanaan tindak lanjut nilai signifikansi $\mathrm{p}$ value menunjukkan $(p=0,030>0,05$ ) yang menandakan bahwa ada perbedaan dari pascates ke tindaklanjut pada kelompok eksperimen.
\end{abstract}

Kata Kunci : pelatihan coaching, kemampuan pemecahan masalah 
Dalam beberapa tahun terakhir, industri batu bara mengalami kelesuan akibat adanya krisis yang terjadi di Eropa. Terjadinya perubahan-perubahan pesat baik dari segi ekonomi dan politik yang terjadi pada industri batu bara saat ini menyebabkan organisasi dituntut untuk mampu bertahan dengan meningkatkan efektivitas dan efisiensinya. Cummings dan Worley (2005) menjelaskan bahwa organisasi adalah suatu sistem yang terbuka (open system) dimana komponen yang terkait dalam organisasi tersebut baik dari segi sumber daya manusia (SDM), material, dan teknologinya sangat dipengaruhi oleh faktor lingkungan eksternal. Dalam situasi yang tidak menentu tersebut, organisasi dituntut untuk lebih adaptif dengan melakukan perubahan-perubahan dan pendekatan dalam melakukan proses kerja yang lebih efektif dan efisien (Schermerhorn, Hunt, Osborn, \& Uhl-Bien, 2010).

Perusahaan tambang batu bara yaitu PT. X yang berada di Kalimantan Timur. PT. X merupakan perusahaan tambang batu bara yang memiliki kegiatan operasi bisnis sumber daya mineral salah satunya yang terbesar di dunia. Berdasarkan hasil asesmen awal, diketahui bahwa PT.X sedang mengalami kelesuan akibat adanya krisis yang terjadi di Eropa yang menyebabkan target produksi PT.X pun menjadi turun pula. Namun demikian, pelaku usaha dunia masih merasa optimis bahwa kondisi yang terjadi pada industri batu bara hanya bersifat sementara.

PT.X mengatasi masalah ini dengan melakukan strategi salah satunya dengan pengembangan managemen sumber daya manusia. Dengan adanya harga batu bara yang turun dan jumlah produksi yang menurun, maka PT.X perlu untuk menjaga performance/kinerja karyawannya sehingga tetap mampu bekerja dengan baik disertai perilaku dalam bekerja yang baik pula dan tidak terpengaruh dengan situasi dan kondisi yang terjadi.

Berdasarkan data lapangan yang ada, yaitu dari hasil FGD (Forum Group Discussion), wawancara, survei dan dari hasil competency rating dapat disimpulkan bahwa kepemimpinan yang dimiliki oleh supervisor masih kurang khususnya pada kemampuan manajerial seperti kemampuan problem solving (pemecahan masalah) atas perilaku karyawan yang berada di bawahnya. Kartono dan Gulo (2000) menjelaskan bahwa problem atau masalah adalah situasi yang tidak pasti, meragukan dan sukar dipahami. Menurut Heppner dan Krauskropf (Heppner, Pretorius, Lee \& Wang, 2002), pemecahan masalah dilakukan ketika individu 
menghadapi masalah kompleks, perubahan secara cepat, dan tujuan yang berhubungan secara langsung dengan kognitif, afektif, dan tindakan yang dilakukan untuk menghadapi masalah baik dari internal maupun eksternal individu.

Salah satu strategi untuk dapat melakukan pemecahan masalah adalah dengan memaksimalkan kemampuan supervisi oleh supervisor kepada bawahannya, yaitu salah satunya dengan praktik coaching. Menurut Cummings dan Worley (2005), coaching adalah usaha untuk meningkatkan kemampuan individu untuk menetapkan dan mencapai tujuan, meningkatkan hubungan interpersonal, menangani konflik ataupun menunjukkan gaya kepemimpinan tertentu. Coaching juga merupakan intervensi jangka pendek yang bertujuan untuk memperbaiki atau meningkatkan kinerja dan mengembangkan suatu kompetensi tertentu (Mosca, Fazzari, \& Burza, 2010).

Penelitian ini peneliti ingin memberikan intervensi berupa pelatihan coaching model GROW (Goal, Reality, Options, Wrap-up) yang dikembangkan semenjak tahun 1980-an oleh Sir John Whitmore (Whitmore, 2009). Penelitian ini dapat memberikan manfaat dalam membantu PT. X untuk mengatasi per- masalahan yang dihadapi dengan memberikan pelatihan coaching sebagai salah satu alternatif solusi yang dapat dilakukan untuk meningkatkan kemampuan pemecahan masalah. Berdasarkan pemaparan permasalahan di atas, penelitian ini bertujuan untuk mengetahui lebih lanjut mengenai bagaimana pengaruh pelatihan coaching terhadap kemampuan pemecahan masalah supervisor PT.X.

\section{METODE PENELITIAN}

\section{Desain Penelitian}

Penelitian ini menggunakan rancangan pretest-posttest control group design, yaitu desain yang dilakukan dengan memberikan pengukuran sebelum dan sesudah perlakuan pada kelompok yang mendapatkan perlakuan dan tidak (Latipun, 2006). Lebih lanjut, menurut Kumar (2005) mengatakan bahwa desain ini merupakan desain yang paling cocok untuk mengukur dampak atau efektifitas program. Kelompok yang mendapatkan intervensi atau perlakuan berupa pelatihan coaching disebut dengan kelompok eksperimen. Sedangkan kelompok yang tidak mendapatkan perlakuan disebut dengan kelompok kontrol. Berikut desain eksperimen yang digunakan : 


\begin{tabular}{|c|c|}
\hline (KK) R O1 & $\mathrm{O} 2$ \\
\hline
\end{tabular}

Skema 1. Rancangan the pretest-posttest control group design

Sumber : Shadish, Cook \& Campbell (2002)

Keterangan :

$\mathrm{KE} \quad=$ Kelompok eksperimen

$\mathrm{KK} \quad=$ Kelompok kontrol

$\mathrm{R} \quad=$ Random

O1 = Pengukuran sebelum diberi perlakuan

$\mathrm{O} 2=$ Pengukuran setelah diberi perlakuan

O3 = Pengukuran setelah diberi perlakuan dengan followup

$\mathrm{X}=$ Perlakuan

\section{Subjek Penelitian}

Subjek yang digunakan dalam penelitian ini adalah supervisor baru (Grade D) di PT.X Kalimantan Timur yang memiliki masa kerja rentang $1-3$ tahun.

\section{Metode Pengumpulan Data}

Metode pengumpulan data pada penelitian ini adalah dengan menggunakan wawancara, kuesioner, dan studi dokumen. Dalam wawancara ini, peneliti menggunakan wawancara terstruktur baik itu secara formal dan informal dan dilakukan baik secara tatap muka secara langsung atau melalui bantuan teknologi seperti penggunaan telepon. Skala yang digunakan dalam penelitian ini adalah skala pemecahan masalah menurut Ellis dan Hunt (1993) yang berjumlah 25 butir, menggunakan model Likert. Alat ukur ini memiliki 4 pilihan jawaban, yaitu STS (Sangat Tidak Sesuai), TS (Tidak Sesuai), S (Sesuai), SS (Sangat Sesuai). Alat ukur terdiri dari 32 butir yang masuk dalam 4 aspek. Analisis dokumen juga dilakukan oleh peneliti untuk mengumpulkan data yang bersumber dari arsip dan dokumen yang ada.

\section{Intervensi}

Intervensi yang diberikan dalam penelitian ini adalah pelatihan coaching. Pelatihan Coaching adalah suatu upaya yang terencana untuk membantu para supervisor dalam mengembangkan pengetahuan, kecakapan dan kemampuan yang berkaitan dengan coaching, yaitu 
proses membantu perseorangan atau organisasi dalam meningkatkan kinerjanya dengan mengatasi hambatan dalam mencapai prestasi kerja yang optimal.

Materi pelatihan yang diberikan kepada supervisor adalah mengenai definisi, tujuan, dan manfaat coaching, karakteristik coach yang efektif, tahapan/proses coaching serta simulasi/praktek coaching itu sendiri berdasarkan model coaching GROW yang dikembangkan oleh Whitmore (2009). Tujuan dari pelatihan coaching ini adalah untuk membantuk supervisor yang mampu mengamalkan coaching terhadap karyawan dibawahnya, termasuk di dalamnya adalah kemampuan dalam memecahan masalah dalam kehidupan sehari-harinya di perusahaan. Waktu pelatihan akan diadakan dalam satu hari dengan jam efektif adalah 450 menit atau 6,75 jam dengan adanya tiga kali waktu istirahat.

Prosedur penelitian ini dibagi menjadi beberapa tahapan, yaitu persiapan penelitian, pengukuran awal (pretest), pelaksanaan penelitian, task assignment, dan pengukuran pascates (posttest) dan pengukuran tindak lanjut (follow up)

\section{Teknik Analisis Data}

Teknik analisis data yang digunakan dalam penelitian ini menggunakan statistik parametrik. Metode yang diguna- kan untuk menguji signifikansi hipotesis komparatif dua sampel yang tidak berhubungan adalah dengan Uji Independent Sample t-test, yaitu untuk menguji ada tidaknya perbedaan tingkat kemampuan pemecahan masalah antara kelompok eksperimen dan kelompok kontrol. Selain itu juga digunakan uji Anova dan Paired sample t-test sebagai uji tambahan yang digunakan untuk mengetahui ada tidaknya perbedaan antara sebelum dan sesudah pemberian perlakuan pada kelompok eksperimen dan kelompok kontrol. Perhitungan selengkapnya menggunakan analisis data penelitian SPSS 20 for windows.

\section{HASIL PENELITIAN}

Angket dibagikan kepada 80 orang supervisor baru di PT.X. Dari 80 angket yang disebarkan untuk uji coba, sebanyak 61 angket yang kembali ke peneliti. Dari 61 angket tersebut, 28 angket dijadikan sebagai data untuk prates dan dari 28 subjek tersebut dibagi menjadi 2 kelompok secara random, yaitu kelompok eksperimen dan kelompok kontrol. Jumlah supervisor pada kelompok eksperimen sebanyak 14 orang dan kelompok kontrol sebanyak 14 orang pula. Namun, pada perjalanannya, terdapat dua subjek yang gugur dikarenakan tidak dapat 
mengisi lembar tindak lanjut karena tidak berada di tempat saat pengambilan data.

Uji validitas item skala pemecahan masalah menunjukkan bahwa dari 32 item yang diujicobakan, terdapat 7 item yang gugur, yaitu item dengan nomor 3 , 5, 6, 16, 18, 22, dan 30. Oleh karena itu, 7 item tersebut dihilangkan untuk melihat koefisien validitasnya. Item yang dianggap valid adalah 25 item dengan koefisien bergerak antara 0,341 sampai dengan 0,700. Berdasarkan data yang diperoleh, dilakukan pula uji reliabilitas. Reliabilitas adalah tingkat kepercayaan hasil suatu pengukuran (Azwar, 2008).
Konstruk atau variabel dikatakan reliabel jika memberikan nilai croncbach Alpha $>0,70$, sedangkan jika nilai $>0,80$ maka nilai tersebut dikatakan baik. Uji reliabilitas terhadap kuesioner pemecahan masalah menghasilkan koefisien reliabilitas alpha sebesar 0,908 yang memiliki arti 0,908 $>0,80$ sehingga skala kemampuan pemecahan masalah dapat dikatakan reliabel sehingga memenuhi syarat untuk dipergunakan sebagai alat ukur pengambilan data penelitian. Berikut adalah deskripsi data penelitian pada tabel di bawah ini :

Tabel 1. Deskripsi data penelitian variabel kemampuan pemecahan masalah

\begin{tabular}{clcccc}
\hline Tahap & Kelompok & Min & Max & Mean & $\begin{array}{c}\text { Standar } \\
\text { Deviasi }\end{array}$ \\
\hline \multirow{2}{*}{ Prates } & Eksperimen & 47 & 96 & 75.00 & 11.292 \\
& Kontrol & 67 & 89 & 79.31 & 6.339 \\
\multirow{2}{*}{ Pascates } & Eksperimen & 66 & 97 & 77.23 & 8.918 \\
& Kontrol & 55 & 97 & 79.92 & 10.589 \\
Tindak & Eksperimen & 71 & 97 & 80.77 & 8.691 \\
Lanjut & Kontrol & 69 & 98 & 83.69 & 8.994 \\
\hline
\end{tabular}

Dari hasil prates, pascates dan pada kelompok eksperimen maupun tindak lanjut, peneliti melakukan kategokelompok kontrol pada tiap tahapan risasi terhadap nilai atau skor kemampengambilan angket. Perbandingan hasil puan pemecahan masalah yang didapatkan masing-masing kelompok baik itu ketiganya dapat dilihat pada tabel berikut: 
Tabel 2. Perbandingan Skor Prates, Pascates, dan Tindak Lanjut Kemampuan Pemecahan Masalah Kelompok Eksperimen

\begin{tabular}{cccccccc}
\hline \multirow{2}{*}{ Skor } & \multirow{2}{*}{ Kategorisasi } & \multicolumn{6}{c}{ Kelompok Eksperimen } \\
\cline { 3 - 7 } & & \multicolumn{2}{c}{ Prates } & \multicolumn{3}{c}{ Pascates } & \multicolumn{2}{c}{ Tindak Lanjut } \\
\cline { 3 - 7 } & Sangat Rendah & 1 & $8 \%$ & 0 & $0 \%$ & 0 & $0 \%$ \\
\hline$X<40$ & Jumlah & $\%$ & Jumlah & $\%$ & Jumlah & $\%$ \\
$40 \leq x \leq 55$ & Rendah & 0 & $0 \%$ & 0 & $0 \%$ & 0 & $0 \%$ \\
$55 \leq X \leq 70$ & Sedang & 2 & $15 \%$ & 3 & $23 \%$ & 0 & $0 \%$ \\
$70<X<85$ & Tinggi & 8 & $62 \%$ & 8 & $62 \%$ & 10 & $77 \%$ \\
$X>85$ & Sangat Tinggi & 2 & $15 \%$ & 2 & $15 \%$ & 3 & $23 \%$ \\
\hline \multicolumn{2}{c}{ Total } & 13 & $100 \%$ & 13 & $100 \%$ & 13 & $100 \%$ \\
\hline
\end{tabular}

Secara keseluruhan, terdapat ke- menjadi sedang, dan dari sedang menjadi naikan perubahan persentase pada ke- tinggi atau sangat tinggi. lompok eksperimen dari sangat rendah

Tabel 3. Perbandingan Skor Prates, Pascates, dan Tindak Lanjut Kemampuan Pemecahan Masalah Kelompok Kontrol

\begin{tabular}{|c|c|c|c|c|c|c|c|}
\hline \multirow{3}{*}{ Skor } & \multirow{3}{*}{ Kategorisasi } & \multicolumn{6}{|c|}{ Kelompok Kontrol } \\
\hline & & \multicolumn{2}{|c|}{ Prates } & \multicolumn{2}{|c|}{ Pascates } & \multicolumn{2}{|c|}{ Tindak Lanjut } \\
\hline & & Jumlah & $\%$ & Jumlah & $\%$ & Jumlah & $\%$ \\
\hline$x<40$ & Sangat Rendah & 0 & $0 \%$ & 0 & $0 \%$ & 0 & $0 \%$ \\
\hline $40 \leq x \leq 55$ & Rendah & 0 & $0 \%$ & 1 & $8 \%$ & 0 & $0 \%$ \\
\hline $55 \leq X \leq 70$ & Sedang & 2 & $15 \%$ & 2 & $15 \%$ & 1 & $8 \%$ \\
\hline $70<X<85$ & Tinggi & 8 & $62 \%$ & 6 & $46 \%$ & 7 & $38 \%$ \\
\hline$X>85$ & Sangat Tinggi & 3 & $23 \%$ & 4 & $31 \%$ & 5 & $54 \%$ \\
\hline \multicolumn{2}{|c|}{ Total } & 13 & $100 \%$ & 13 & $100 \%$ & 13 & $100 \%$ \\
\hline
\end{tabular}

Selanjutnya, pada akhir pelaksanaan pelatihan coaching, peserta pelatihan diminta untuk memberikan penilaian atau evaluasi terkait kegiatan pelatihan yang telah dilaksanakan apakah telah berjalan baik, tepat sasaran dan dapat meningkatkan pemahaman dan perilaku peserta pelatihan mengenai coaching.
Sesuai dengan tahapan evaluasi pada kegiatan pelatihan oleh Kirkpatrick dan Kirkpatrick (2006), dilakukan evaluasi pada level 1 yaitu reaksi peserta, level 2 yaitu pemahaman atau pengetahuan peserta dan level 3 yaitu perilaku terhadap pelatihan ini. Berikut adalah deskirpsi skor hasil evaluasi reaksi. 
Tabel 4. Deskripsi Skor Hasil Evaluasi Reaksi

\begin{tabular}{|c|c|c|c|}
\hline \multirow{2}{*}{ Skor } & \multirow{2}{*}{ Kategorisasi } & \multicolumn{2}{|c|}{ Peserta } \\
\hline & & Jumlah & $\%$ \\
\hline$x<10.006$ & Sangat Tidak Puas & 0 & $0 \%$ \\
\hline $10.006 \leq x \leq 20.002$ & Tidak Puas & 0 & $0 \%$ \\
\hline $20.002 \leq X \leq 29.998$ & Cukup Puas & 1 & $8 \%$ \\
\hline $29.998 \leq X \leq 39.994$ & Puas & 11 & $84 \&$ \\
\hline$x>39.994$ & Sangat Puas & 1 & $8 \%$ \\
\hline \multicolumn{2}{|c|}{ Total } & 13 & $100 \%$ \\
\hline
\end{tabular}

Berdasarkan analisis terhadap evaluasi reaksi, diperoleh hasil bahwa kegiatan pelatihan coaching diasumsikan sesuai dengan kebutuhan para peserta pelatihan saat ini, dan semua peserta sudah menilai pelatihan coaching yang diselenggarakan berjalan baik dan dirasakan memuaskan bagi seluruh peserta yang mengikuti pelatihan. Selanjutnya adalah evaluasi level pengetahauan sebagai berikut :

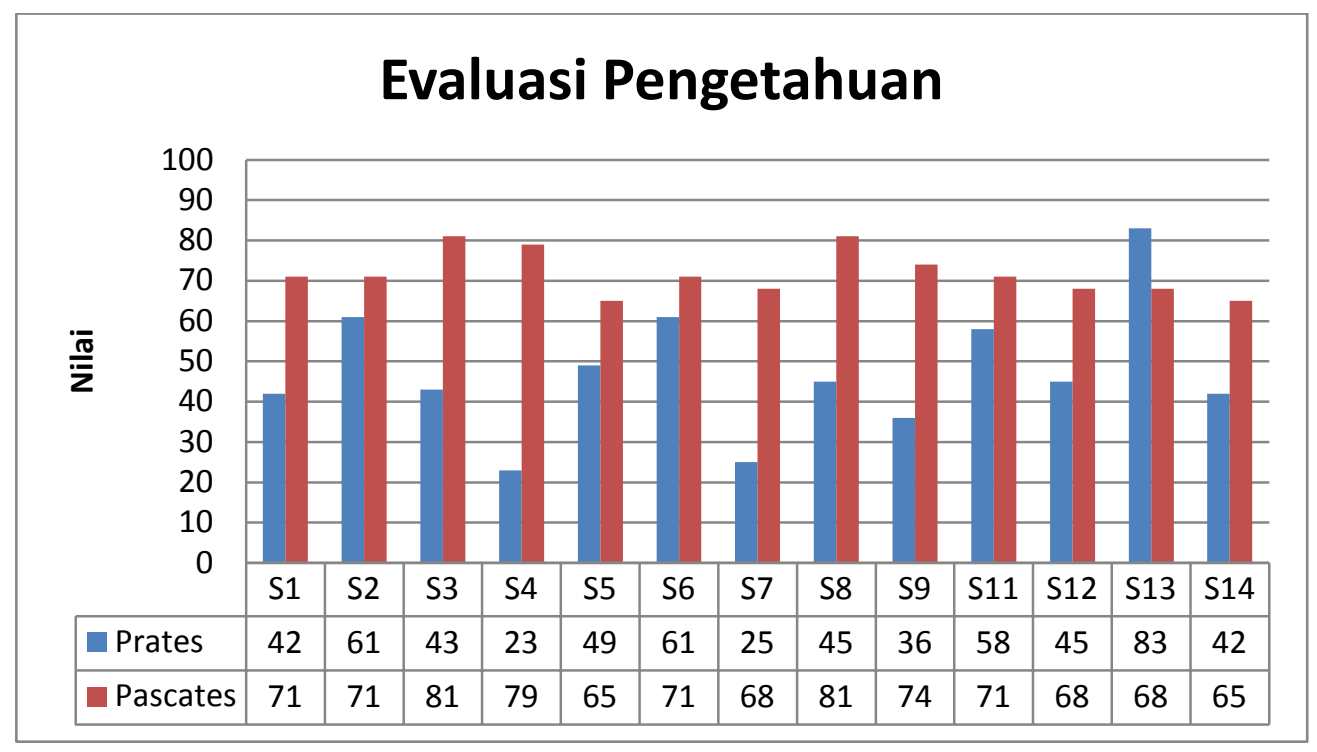

Gambar 1. Grafik Perbandingan Skor Jawaban Prates dan Pascates Peserta

Berdasarkan grafik di atas, dapat diketahui bahwa seluruh peserta pelatihan menunjukkan peningkatan pengetahu- an yang signifikan. Pada perhitungan skor di awal pelatihan, skor yang diperoleh peserta berkisar antara 23 hingga 83 
dengan mean 47,15 . Kemudian setelah mengikuti pelatihan, skor peserta meningkat antara rentang 65 hingga 88 dengan mean sebesar 71,77 . Selanjutnya adalah dengan menggunakan uji analysis Paired Sample $t$-test:

Tabel 5. Hasil Analisis Paired Sample t-test Level Pengetahuan

\begin{tabular}{cccccc}
\hline Pengukuran & Mean & SD & $\begin{array}{c}\text { Mean } \\
\text { Difference }\end{array}$ & Nilai - t & Sig. \\
\hline Prates & 47.15 & 15.989 & -24.614 & -4.836 & 0.000 \\
Pascates & 71.77 & 5.510 & & & \\
\hline
\end{tabular}

Berdasarkan tabel di atas, dapat diketahui bahwa mean pascates adalah sebesar 71,77 lebih tinggi dibandingkan mean prates 47,15 . Selain itu apabila dilihat dari nilai t sebesar $-4,836$ dengan signifikansi $0.000(p<0.05)$ maka menunjukkan bahwa terdapat perbedaan skor yang signifikan antara prates dan pascates. Dengan demikian dapat ditarik kesimpulan bahwa keseluruhan peserta mengalami proses pembelajaran dan peningkatan pemahaman/pengetahuan mengenai materi coaching tersebut.

Evaluasi perilaku juga peneliti lakukan walaupun tidak dapat dilakukan pada seluruh subjek. Terdapat 5 orang yang melaksanakan tugas melakukan coaching kepada bawahannya. Hasil yang didapat adalah masih terdapat beberapa karyawan yang belum sepenuhnya memahami tata cara dalam mengisi form coaching yang telah diberikan, walaupun secara praktik para supervisor sudah mampu memahami alur dalam melakukan coaching yang baik dan benar. Supervisor masih perlu melakukan praktik terus menerus untuk dapat melatih kemampuan melakukan coaching yang baik dan benar. Untuk melakukan uji hipotesis, terlebih dahulu dilakukan uji normalitas yaitu sebagai berikut:

Tabel 6. Hasil Uji Normalitas Sebaran Kemampuan Pemecahan Masalah

\begin{tabular}{lccccl}
\hline \multirow{2}{*}{ Pengukuran } & \multicolumn{2}{c}{ Eksperimen } & \multicolumn{2}{c}{ Kontrol } & \multirow{2}{*}{ Keterangan } \\
\cline { 2 - 5 } & K-St & $\mathbf{P}$ & K-St & $\mathbf{P}$ & \\
\hline Prates & 0.654 & 0.787 & 0.370 & 0.999 & Normal \\
Pascates & 0.634 & 0.816 & 0.594 & 0.873 & Normal \\
\hline
\end{tabular}


Berdasarkan hasil uji normalitas dengan menggunakan one sample kolmogrof-smirnov test di atas, dapat terlihat bahwa nilai probabilitas kelompok eksperimen pada skala prates adalah 0,787 dan 0,816 untuk skala pascates. Hal ini dapat diartikan bahwa $0.787>0.05$ dan $0.816>0.05$. Dengan demikian dapat disimpulkan bahwa data penelitian diambil dari populasi yang berdistribusi normal. Begitu pula nilai probabilitas kelompok kontrol pada skala prates adalah 0.999 dan pada pascates adalah 0,873 . Hal ini dapat diartikan bahwa $0,996>0,05$ dan 0,873>0,05 dengan demikian dapat disimpulkan bahwa data peneliian diambil dari populasi yang berdistribusi normal.

Hasil uji homogenitas untuk kemampuan pemecahan masalah menunjukkan nilai levene statistik $=0,565$ dan nilai $p=0,641$ dengan nilai $p>0,05$. Berdasarkan hasil uji homogenitas tersebut maka dapat dikatakan kuesioner kemampuan pemecahan masalah adalah homogen.

Selanjutnya adalah uji hipotesis dengan analisis uji parametrik karena semua persyaratan memenuhi untuk dilakukannya uji parametrik. Hasil pengukuran Uji F Anova pada data penelitian pra-pascates dapat dilihat pada tabel berikut ini:

Tabel 7. Uji F - Anova Kemampuan Pemecahan Masalah

\begin{tabular}{lrrrrr}
\hline & Sum of Squares & Df & Mean Square & F & Sig. \\
\hline Between Groups & 194.058 & 3 & 64.686 & .667 & .577 \\
Within Groups & 4656.000 & 48 & 97.000 & & \\
\hline Total & 4850.058 & 51 & & & \\
\hline
\end{tabular}

Berdasarkan hasil analisis uji hipotesis di atas ( $p>0.01)$, maka dapat disimpulkan bahwa pemberian pelatihan coaching yang telah diselenggarakan ketika dilakukan pengukuran dua minggu setelahnya terbukti tidak memberikan pengaruh secara signifikan terhadap peningkatan kemampuan pemecahan masalah.
Adapun pengujian hipotesis dalam penelitian ini menggunakan analisis Independent sample t-test. Analisis Independent sample t-test digunakan untuk menguji signifikansi beda rata-rata dua kelompok dan digunakan untuk menetapkan apakah nilai variabel tertentu berbeda di antara dua kelompok. Analisis Independent sample t-test digunakan 
untuk mengetahui perbedaan pengaruh pelatihan coaching terhadap kemampuan pemecahan masalah supervisor sebelum dan sesudah supervisor diberikan pelatihan. Berikut hasil uji hipotesis yang meng- gunakan analisis Independent sample ttest pada dua kelompok yaitu kelompok eksperimen dan kelompok kontrol saat prates.

Tabel 8. Hasil Uji Hipotesis Skor Prates Kemampuan Pemecahan Masalah Kelompok Eksperimen dan Kontrol

\begin{tabular}{lccccc}
\hline Kelompok & Mean & $\begin{array}{c}\text { Standar } \\
\text { Deviation }\end{array}$ & $\begin{array}{c}\text { Mean } \\
\text { Difference }\end{array}$ & Nilai -t & Sig. \\
\hline Eksperimen & 75.00 & $\begin{array}{c}11.740 \\
6.588\end{array}$ & -4.308 & -1.154 & 0.260 \\
Kontrol & 79.31 & 6.588 & & & \\
\hline
\end{tabular}

Berdasarkan hasil analisis data yang diperoleh di atas, menunjukkan bahwa sebelum diberi perlakuan, nilai mean pada kelompok eksperimen adalah sebesar 75,00 dan kelompok kontrol sebesar 79,31 dengan perbedaan mean adalah -4,308. Adapun nilai t-hitung sebesar $-1,154$ dan nilai signifikansi $p$ value $(0,260>0,05)$. Hal ini berarti tidak ada perbedaan kemampuan pemecahan masalah yang signifikan antara kelompok eksperimen dan kelompok kontrol sebelum diberi pelatihan.

Adapun hasil pascates pada kelompok eksperimen dan kelompok kontrol dapat dilihat pada tabel berikut ini :

Tabel 9. Hasil Uji Hipotesis Skor Kemampuan Pemecahan Masalah Pascates Kelompok Eksperimen dan Kontrol

\begin{tabular}{lccccc}
\hline Kelompok & Mean & $\begin{array}{c}\text { Standar } \\
\text { Deviation }\end{array}$ & $\begin{array}{c}\text { Mean } \\
\text { Difference }\end{array}$ & Nilai -t & Sig. \\
\hline Eksperimen & 77.23 & 9.239 & -2.692 & -0.675 & 0.506 \\
Kontrol & 79.92 & 11.019 & & & \\
\hline
\end{tabular}

Berdasarkan hasil analisis data sebesar 79,92 dengan perbedaan rata-rata yang diperoleh menunjukkan bahwa setelah diberi perlakuan, nilai rata-rata adalah 2,692. Adapun nilai t-hitung pada kelompok eksperimen adalah sebesar 77,23 dan kelompok kontrol sebesar 0,675 dengan nilai signifikansi $p$ value $(p=0,506>0,05)$. Hal ini berarti tidak ada perbedaan skor pascates yang 
signifkan antara kelompok eksperimen dan kontrol.

Berdasarkan hasil analisis data prates dan pascates pada kelompok eksperimen dan kontrol yang diperoleh di atas, dapat ditarik kesimpulan bahwa tidak terdapat pengaruh yang signifikan terhadap kemampuan pemecahan masalah supervisor antara sebelum dan sesu- dah diberikan pelatihan coaching. Hasil analisis data ini menunjukkan bahwa hipotesis yang dikemukakan oleh peneliti tidak diterima. Selanjutnya peneliti melakukan analisis terhadap data skala pengukuran tindak lanjut, untuk melihat sejauhmana konsistensi perubahan yang terjadi.

Tabel 10. Hasil Uji Hipotesis Skor Tindak Lanjut Kemampuan Pemecahan Masalah Kelompok Eksperimen dan Kontrol

\begin{tabular}{lccccc}
\hline Kelompok & Mean & $\begin{array}{c}\text { Standar } \\
\text { Deviation }\end{array}$ & $\begin{array}{c}\text { Mean } \\
\text { Difference }\end{array}$ & Nilai -t & Sig. \\
\hline Eksperimen & 80.77 & 8.691 & -2.923 & -0.843 & 0.408 \\
Kontrol & 83.69 & 8.994 & & & \\
\hline
\end{tabular}

Berdasarkan hasil analisis data yang diperoleh saat tindak lanjut, menunjukkan bahwa nilai rata-rata pada kelompok eksperimen adalah sebesar 80,77 dan kelompok kontrol sebesar 83,69 dengan perbedaan rata-rata adalah 2,923 . Adapun nilai t-hitung sebesar 0,843 dengan nilai signifikansi $p$ value $(p=0,408>$ $0,05)$. Hal ini menunjukkan tidak ada perbedaan skor tindak lanjut yang signifkan antara kelompok eksperimen dan kontrol.

Peneliti kemudian melakukan uji analisis tambahan terhadap data pene- litian sehingga hasil dari pembuktian analisis hipotesis yang telah dilakukan lebih komprehensif. Analisis uji beda tambahan yang dilakukan adalah dengan menggunakan analisis paired sample $t-$ test. Analisis Paired sample $t$ - test dilakukan untuk mengetahui perbedaan antara skor prates dan pascates yang diperoleh masing-masing kelompok eksperimen dan kelompok kontrol. Analisis ini dilakukan untuk melihat sejauh mana sumbangan skor prates dan pascates dari masing-masing kelompok sebagai data tambahan pendukung hipotesis. 
Tabel 11. Hasil Uji Paired Sample t-test Kelompok Eksperimen dan Kontrol

\begin{tabular}{lccccc}
\hline Kelompok & $\begin{array}{c}\text { Mean } \\
\text { Prates }\end{array}$ & $\begin{array}{c}\text { Mean } \\
\text { Pascates }\end{array}$ & $\begin{array}{c}\text { Mean } \\
\text { Difference }\end{array}$ & Nilai -t & Sig. \\
\hline Eksperimen & 75.00 & 77.23 & -2.231 & -0.797 & 0.441 \\
Kontrol & 79.31 & 79.92 & -0.615 & -0.272 & 0.790 \\
\hline
\end{tabular}

Berdasarkan hasil analisis data melalui paired sample test, menunjukkan bahwa terdapat peningkatan rata-rata prates pada kelompok eksperimen. Sebelum diberikan perlakuan, nilai ratarata prates pada kelompok eskperimen sebesar 75 sedangkan setelah diberikan perlakuan pelatihan coaching, nilai ratarata pascates meningkat menjadi 79,31 dengan perbedaan selisih nilai rata-rata antara skor prates dan pascates sebesar 2,231. Hal ini menunjukkan bahwa terdapat peningkatan skor kemampuan pemecahan masalah pada subjek setelah diberikan perlakuan berupa pelatihan coaching. Namun, walaupun nilai mean mengalami peningkatan, tetapi nilai signifikansi menunjukkan nilai yang lebih besar dari level of significant ( $p=0,441$ $>0,05)$. Hal ini menunjukkan tidak ada perbedaan skor kemampuan pemecahan masalah yang cukup siginifikan antara sebelum dan sesudah diberikan pelatihan pada kelompok eksperimen.

Sementara hasil analisis dari data prates dan pascates pada kelompok kontrol menunjukkan bahwa nilai ratarata prates kelompok kontrol terhadap kemampuan pemecahan masalah yang awalnya sebesar 79,31 saat pascates juga mengalami peningkatan menjadi 79,92. Hal ini menunjukkan peningkatan mean skor sebesar 0,615. Namun demikian, peningkatan nilai rata-rata pada kelompok eksperimen lebih besar jika dibandingkan dengan kelompok kontrol yaitu sebesar 2,231. Selain itu nilai signifikansi kelompok kontrol antara prates dan pascates adalah $0,790(p<0,05)$. Hal ini menunjukkan tidak ada perbedaan yang signifikan kemampuan pemecahan masalah antara prates dan pascates pada kelompok kontrol.

Analisis Paired sample $t$ - test selanjutnya dilakukan untuk mengetahui perbedaan antara skor pascates dengan tindak lanjut yang diperoleh masingmasing kelompok eksperimen dan kelompok kontrol. Analisis ini dilakukan untuk melihat sejauh mana sumbangan skor pascates dan tindak lanjut dari masing-masing kelompok. 
Tabel 12. Hasil Uji Paired Sample t-test Kelompok Eksperimen dan Kontrol

\begin{tabular}{lccccc}
\hline Kelompok & $\begin{array}{c}\text { Mean } \\
\text { Pascates }\end{array}$ & $\begin{array}{c}\text { Mean } \\
\text { Tindak } \\
\text { Lanjut }\end{array}$ & $\begin{array}{c}\text { Mean } \\
\text { Difference }\end{array}$ & Nilai -t & Sig. \\
\hline Eksperimen & 77.23 & 80.77 & -3.538 & -2.458 & 0.030 \\
Kontrol & 79.92 & 83.69 & -3.769 & -2.264 & 0.043 \\
\hline
\end{tabular}

Berdasarkan hasil analisis data melalui paired sample test menunjukkan bahwa terdapat peningkatan rata-rata saat tindak lanjut pada kelompok eksperimen. Sebelum diberikan perlakuan, nilai ratarata pascates pada kelompok eskperimen sebesar 77,23 sedangkan setelah diberikan pengukuran tindak lanjut, nilai ratarata meningkat menjadi 79,92 dengan perbedaan selisih nilai rata-rata antara skor pascates dengan tindak lanjut sebesar 3,538. Hal ini menunjukkan bahwa terdapat peningkatan skor kemampuan pemecahan masalah pada subjek setelah 2 minggu pascates diberikan. Selain itu nilai signifikansi juga menunjukkan nilai yang lebih kecil dari level of significant $(p=0,030>0,05)$. Hal ini menunjukkan ada perbedaan skor kemampuan pemecahan masalah yang cukup siginifikan antara saat pascates dengan tindak lanjut pada kelompok eksperimen.

Dari grafik tersebut di atas, rata-rata terdapat kenaikan skor kemampuan pe- mecahan masalah pada supervisor yaitu dari skor pascates ke tindak lanjut sehingga dapat ditarik kesimpulan bahwa terdapat pengaruh yang signifikan terhadap peningkatan kemampuan pemecahan masalah supervisor antara pascates dengan tindak lanjut.

Sementara hasil analisis dari data pascates dan tindak lanjut pada kelompok kontrol juga menunjukkan peningkatan yaitu yang awalnya nilai rata-rata sebesar 79,92 saat pascates mengalami peningkatan menjadi 83.69. Hal ini menunjukkan peningkatan mean skor sebesar 3.769. Selain itu nilai signifikansi kelompok kontrol antara prates dan pascates adalah $0,043(p<0,05)$. Hal ini menunjukkan ada perbedaan yang signifikan kemampuan pemecahan masalah antara pascates dan tindak lanjut pada kelompok kontrol. 


\section{PEMBAHASAN}

Permasalahan utama yang diteliti dalam penelitian ini adalah apakah pelatihan coaching dapat meningkatkan kemampuan pemecahan masalah pada supervisor. Hipotesis dalam penelitian adalah ada pengaruh positif pelatihan coaching terhadap tingkat kemampuan pemecahan masalah. Dari hasil uji beda yang telah dilakukan, diperoleh hasil bahwa variabel kemampuan pemecahan masalah pada kelompok eksperimen dan kontrol pada saat pelaksanaan prates dan pascates diperoleh nilai skor $\mathrm{F}$ sebesar 0,677 dengan $p=0,577(p>0,05)$. Hal ini menunjukkan bahwa tidak ada perbedaan yang signifikan antara skor kemampuan pemecahan masalah pada kelompok eksperimen setelah diberikan pelatihan coaching dengan kelompok kontrol yang tidak diberikan pelatihan coaching. Hal ini menunjukkan bahwa hipotesis awal yang berbunyi ada pengaruh positif pelatihan coaching terhadap tingkat kemampuan pemecahan masalah pada supervisor tidak terbukti atau tidak diterima.

Salah satu pendekatan yang dilakukan peneliti guna meningkatkan kemampuan pemecahan masalah adalah dengan memberikan pelatihan coaching kepada supervisor. Tujuan dari diada- kannya pelatihan coaching tersebut adalah melatih seorang supervisor mampu melakukan identifikasi masalah, pencarian informasi yang baik dalam proses coaching dengan kemampuan bertanya dan melakukan feedback yang baik, komunikasi yang efektif, serta peningkatan keahlian, kompetensi dalam melakukan coaching, serta kepercayaan diri dan motivasi. Dengan memahami bagaimana melakukan coaching dengan baik, maka diharapkan supervisor dapat meningkatkan kemampuan pemecahan masalah dengan baik pula.

Menurut Whitmore (2009) menjelaskan bahwa situasi-situasi di mana dalam situasi tersebut membutuhkan coaching adalah yaitu sebagai pemecahan masalah atau pemecahan masalah pada karyawan. Coaching, menurut Wilson (2011), adalah metode untuk membantu perseorangan atau organisasi dalam meningkatkan kinerjanya dengan mengatasi hambatan dan tantangan yang ada. Adapun seorang supervisor merupakan pihak yang memiliki peran sebagai coach dan karyawan yang berada dibawahnya berperan sebagai coachee.

Terdapat langkah-langkah yang harus dilakukan dalam melakukan coaching. Salah satu model coaching yaitu GROW yang dikembangkan oleh Whitmore (2009) dijelaskan 4 langkah dalam mela- 
kukan coaching, yaitu Goal (tujuan), Reality (realitas), Options (pilihan), dan Warm-up (ringkasan). Langkah pertama adalah menetapkan tujuan (goal). Seorang coach harus dapat membantu coachee mengidentifikasi tujuan atas permasalahan yang dihadapi atau tujuan yang ingin diraih dari coachee dan fokus pada solusi dari masalah tersebut. Coachee akan diminta untuk menceritakan masalah atau kendala yang dialami terlebih dahulu, kemudian coach diharapkan akan menggiring pada penetapan tujuan. Oleh karena itu, tahapan awal ini menuntut seorang coach dalam hal ini supervisor untuk dapat melakukan identifikasi masalah coachee dengan baik sehingga proses penggiringan tujuan pun dapat berjalan sesuai dengan apa yang diinginkan. Adapun identifikasi masalah yang baik yang dilakukan supervisor akan mempengaruhi kemampuan pemecahan masalah, karena menurut Stein dan Book (2004), pemahaman masalah/perumusan masalah hingga masalah dapat teridentifikasi dengan baik merupakan langkah pertama yang harus dilakukan dalam melakukan pemecahan masalah.

Menurut D'Zurilla, Nezu dan Maydeu-Olivares (2004), bahwa salah satu aspek dalam pemecahan masalah adalah mampu mendefinisi masalah/perumusan.
Dalam definisi masalah dan perumusan, individu mencoba untuk menjelaskan dan memahami masalah dengan mengumpulkan sebanyak mungkin faktafakta spesifik dan konkrit tentang masalah, mengidentifikasi tuntutan dan hambatan, dan mengatur tujuan pemecahan masalah yang realistis (misalnya, mengubah situasi untuk lebih baik, menerima situasi dan meminimalkan gangguan emosi). Dalam hal ini, seorang supervisor harus memiliki kemampuan bertanya yang baik untuk mengumpulkan fakta-fakta yang spesifik dan mengatur tujuan yang realistis nantinya. Adapun peran coach, menurut Thorne (2005), dalam kegiatan coaching adalah seperti mengajukan pertanyaan untuk keperluan analisis, menggunakan pertanyaan terbuka untuk menggali informasi lebih dalam, dapat memberikan saran-saran agar wawasan dari pada coachee lebih terbuka, menawarkan ide dan mengembangkannya bersama serta dapat memberikan umpan balik.

Apa yang terjadi di lapangan berdasaran hasil pengamatan peneliti mengenai pelaksanaan coaching adalah supervisor yang melakukan praktik coaching belum mampu sepenuhnya melakukan identifikasi pada tahap goal dengan baik. Adanya asumsi permasalahan yang terlalu cepat dari supervisor 
dapat menyebabkan ketidaksepemahaman antara supervisor dan bawahan yang dicoaching. Hal ini nampak pula pada pengisian kolom tujuan di lembar kerja coaching oleh supervisor yang menunjukkan supervisor belum sepenuhnya memahami bagaimana melakukan identifikasi masalah pada tahap tujuan.

Aspek selanjutnya adalah pemecahan masalah. Ellis dan Hunt (2004) menjelaskan bahwa pemecahan masalah terdiri atas mampu memahami masalah, mampu mencari dan menilai alternatif solusi, mampu melaksanakan solusi, mampu melaksanakan evaluasi terhadap solusi yang telah di laksanakan. Berdasarkan hasil analisis data angket yang dilakukan oleh penelitian, nilai rata-rata paling rendah yang dimiliki oleh supervisor adalah pada aspek pelaksanaan evaluasi terhadap pemecahan masalah. Hal ini dapat terjadi karena praktik coaching yang dilakukan kurang efektif dan waktu untuk melakukan evaluasi juga tidak banyak. Hal ini pun dapat mempengaruhi kemampuan pemecahan masalah secara keseluruhan.

Faktor yang mempengaruhi kemampuan pemecahan masalah lainnya adalah keahlian, kemampuan yang diasah, kompetensi, serta pengalaman. Seseorang yang ahli dianggap lebih mampu menyelesaikan masalah di bidangnya dibandingkan dengan para pemula (Sternberg, 2008). Adapun untuk menjadi ahli, dibutuhkan adanya latihan atau kemampuan yang terus diasah sehingga dapat meningkatkan kompetensi. Banyak penelitian yang menunjukkan bahwa latihan akan menjadikan seseorang menjadi sempurna (Stenberg, 2008). Praktik dianggap penting untuk membangun basis bagi pengetahuan dan keahlian.

Para subjek penelitian yang berada pada kelompok eksperimen belum sepenuhnya mampu mengaplikasikan coaching di tempat kerja sehingga pengetahuan tentang coaching hanya sekedar mengetahui saja, namun tidak sampai pada praktik di lapangan. Selain itu, supervior yang sudah melakukan praktik tidak semuanya dapat melakukan coaching dengan baik dan sesuai dengan aturan yang ada pada tiap tahapannya. Oleh karena itu, pelatihan coaching belum menginternalisasi secara sempurna ke dalam diri subjek. Hal ini dapat menyebabkan hasil pengukuran menjadi tidak signifikan.

Penelitian ini dilakukan dengan dua macam validitas, yaitu validitas yang berhubungan dengan efek yang ditimbulkan (internal validity) dan validitas yang berhubungan dengan penerapan hasil eksperimen (eksternal validity). 
Shadish, Cook, dan Campbell (2002) menjelaskan ada beberapa faktor yang mengancam validitas internal penelitian yang apabila tidak dikendalikan dapat menimbulkan invaliditas suatu eksperimen. Gangguan validitas tersebut dapat berupa, (a) historis, yaitu kejadiankejadian di lingkungan penelitian di luar perlakuan yang muncul selama penelitian berlangsung, (b) maturasi, proses yang terjadi pada subjek sehingga menimbulkan perubahan, (c) testing, kenaikan skor pascates karena subjek pernah mengerjakan prates sebelumnya, (d) instrumentasi, cara pengukuran dilakukan, (e) regresi statistik, yaitu kecenderungan hasil pengukuran variabel terikat untuk bergeser ke arah pusat (ke arah mean), (f) bias dalam seleksi, yaitu sejumlah perbedaan sistematis yang terjadi pada perbandingan antar kelompok sebelum pemberian perlakuan, (g) subjek keluar, yaitu kehilangan subjek selama penelitian berlangsung, (h) difusi atau imitasi perlakuan, terjadi ketika adanya interkasi antara kelompok kontrol dengan eksperimen, (i) demoralisasi, terjadi ketika kelompok kontrol mempelajari atau menuntut perlakuan yang sama.

Untuk menjaga validitas internal pada penelitian ini dilakukan beberapa usaha, di antaranya dengan pengelompokan unit eksperimen secara objektif sehingga mengurangi bias dalam seleksi. Kelompok eksperimen maupun kelompok kontrol juga mampu mewakili populasi penelitian secara luas. Uji normalitas yang dilakukan menunjukkan bahwa kelompok penelitian tergolong representatif atau dapat mewakili populasi yang ada. Pembentukan kelompok kontrol juga dilakukan untuk mengendalikan faktor historis, maturasi, testing dan instrumentasi. Kelompok eksperimen dan kelompok kontrol berada pada wilayah, latar belakang keadaan, dan kebijakan institusi yang sama. Kelompok kontrol dijadikan sebagai pembanding pada penelitian ini sebab segala kemungkinan perubahan berupa perubahan situasi, lingkungan serta perubahan laiinnya yang dialami kelompok eksperimen juga berdampak pada kelompok kontrol. Faktor instrument juga dikontrol dengan pemberikan instrument yang valid dan reliabel serta dilakukan prosedur yang tepat. Namun, validitas internal pada penelitian ini dapat terganggu dikarenakan subjek yang mengisi angket tidak secara bersamaan dalam mengisi angket, dimana peneliti menggunakan dua metode dalam memberikan angket yaitu langsung menemui subjek dan juga melalui email kepada subjek dan adakalanya harus menunggu dengan meninggalkan angket tersebut kepada 
subjek penelitian karena kesibukan karyawan, sehingga tidak dapat langsung segera diisi.

Selain validitas internal yang memengaruhi penelitian eksperimen ini, terdapat pula faktor lain, seperti validitas eksternal. Validitas eksternal berhubungan dengan penerapan hasil eksperimen. Ada beberapa faktor eksternal yang dapat mempengaruhi subjek dan tidak dapat dikontrol oleh peneliti sehingga dapat mempengaruhi hasil penelitian. Faktor tersebut antara lain tipe kepribadian dan lingkungan sosial.

Berdasarkan hasil wawancara dan observasi peneliti terhadap subjek penelitian, tampak bahwa pada kelompok eksperimen dan kontrol sama-sama memiliki kemauan belajar yang tinggi. Adanya situasi bahwa supervisor baru adalah supervisor yang sama-sama sedang berada pada masa pengembangan (Management Development Program/ MDP) dan masih dalam penilaian penuh oleh section Learning and Development, menyebabkan adanya perasaaan atas kewajiban dalam menaikkan nilai kompetensi yang terbukti dengan hasil angket pada kedua kelompok sama-sama naik. Oleh karena itu, pada hasil uji hipotesis, nampak bahwa baik kelompok kontrol dan eksperimen sama-sama menunjukkan kenaikan skor sehingga ketika diukur saat pascates menunjukkan hasil yang kurang signifikan. Agar pengukuran dapat lebih objektif, maka dapat direkomendasikan menggunakan pengukuran dari atasan sehingga pengukuran bisa lebih objektif, dibandikan dengan pengukuran yang dilakukan langsung oleh supervisor (self asssessment). Hal ini dapat menjadi perhatian dan pertimbangan pada penelitian selanjutnya yang ingin mengambil topik yang sama seperti penelitian penulis.

Kemampuan pemecahan masalah juga tidak serta merta dapat diukur hanya dalam hitungan minggu. Oleh karena itu, walau saat pascates tidak terdapat perbedaan yang signifikan namun saat tindak lanjut terdapat perbedaan yang cukup signifikan dari pascates ke tindak lanjut pada kelompok eskperimen. Hal ini menunjukkan bahwa subjek membutuhkan adaptasi dengan adanya waktu yang lebih untuk dapat menerapkan coaching secara terus menerus sehingga pengetahuan yang didapat dapat diterapkan dan nantinya akan berpengaruh pada kemampuan pemecahan masalah.

Faktor lain yang dapat memengaruhi hipotesis tidak diterima adalah fakta bahwa nilai prates pada subjek di dua kelompok, yaitu kelompok eksperimen dan kontrol rata-rata memiliki kategorisasi tinggi. Hal ini menyebabkan peng- 
ukuran setelahnya tidak terlalu nampak perbedaannya, seharusnya peneliti dapat melakukan randomisasi pada subjek yang memiliki kategorisasi rendah agar dapat dengan mudah dipantau saat pascates.

Hasil penelitian menunjukkan bahwa hipotesis tidak diterima, namun jalannya penelitian tetap memiliki manfaat terhadap subjek penelitian. Pelatihan yang dilakukan mampu memberikan pengetahuan kepada subjek mengenai materi coaching yang selama ini belum sepenuhnya dimengerti oleh supervisor. Hal ini bisa terlihat dari hasil evaluasi pengetahuan berupa tes kognitif yang dilakukan sebelum dan susudah pelatihan. Hasil skor tes kognitif meningkat. Selain itu, dengan adanya pelatihan coaching ini, para supervisor menjadi lebih terbuka dalam menyampaikan ideide dan masukannya, lebih baik dalam berkomunikasi dan paham bagaimana mengidentifikasi permasalahan bawahan. Hal ini diketahui dari hasil wawancara penelitian dengan beberapa orang setelah dua minggu pelatihan berakhir.

\section{SIMPULAN DAN SARAN}

\section{Simpulan}

Penelitian ini belum mampu membuktikan bahwa ada pengaruh pelatihan coaching terhadap kemampuan peme- cahan masalah. Pelatihan coaching yang diberikan kepada kelompok ekspri-men disusun dengan mengacu pada Coaching Model GROW (Whitmore, 2009).

Belum terbuktinya pelatihan coaching dalam meningkatkan kemampuan pemecahan masalah disebabkan beberapa hal, yaitu belum mampunya subjek eksperimen secara keseluruhan dalam menerapkan coaching kepada bawahannya. Adanya kewajban dalam meningkatkan nilai kompetensi pada kelompok kontrol juga turut memberikan pengaruh (program MDP), sehingga nilai awal (prates) pada kedua kelompok sudah cukup tinggi. Di samping itu, kurangnya pengontrolan terhadap faktor-faktor validitas internal dan validitas eksternal juga turut menyebabkan kurang mampunya pelatihan coaching dapat memengaruhi kemampuan pemecahan masalah. Kelompok eksperimen membutuhkan waktu lebih lama untuk beradaptasi dan melaksanakan coaching. Pada sisi lain, dengan adanya pelatihan coaching ini, para supervisor merasa menjadi lebih terbuka dalam menyampaikan ide-ide dan masukannya, lebih baik dalam berkomunikasi, dan paham bagaimana mengidentifikasi permasalahan bawahan. 
Saran

Saran kepada penelitian selanjutnya adalah dapat melakukan pengukuran dengan periode yang relatif lebih panjang. Hal ini disebabkan ada beberapa individu yang membutuhkan waktu yang lebih lama untuk dapat menginternalisasikan habit atau perilaku yang didapatkan ketika pelatihan. Untuk pelatihan selanjutnya, peneliti menyarankan agar dapat dilaksanakan lebih lama dari peneliti sebelumnya, yaitu dapat dibagi dalam dua hari, sehingga wawasan dan simulasi yang diberikan dapat sepenuhnya dimengerti dan dipahami oleh supervisor. Pengukuran angket sebaiknya tidak menggunakan self assessment oleh subjek, melainkan dapat dilakukan oleh atasan atau bawahan subjek agar jawaban bisa lebih objektif. Selain itu, peneliti diharapkan lebih ketat dalam mengontrol faktor-faktor yang dapat mempengaruhi validitas internal dan eksternal, sehingga efektivitas penelitian dapat terjaga.

\section{DAFTAR PUSTAKA}

Azwar, S.S (2008). Penyusunan skala psikologi. Yogyakarta: Pustaka Pelajar
Cummings, T. G. \& Worley, C. G. (2005). Organization development and change (9th ed.). Mason, $\mathrm{OH}$ : South-Western Cengage Learning

D'Zurilla, T.J., Nezu, A.M, \& MaydeuOlivares, A. (2004). What is social problem solving? Meaning, models, and measures. In E.C. Chang, T.J. D'Zurilla \& L. Sanna, (Eds.) Social Problem Solving: Theory, research, and training (pp. 11-27), Washington, DC: American Psychological Association.

Ellis, H.C \& Hunt, R.R. (1993). Fundamentals of cognitive psychology. $5^{\text {th }}$ Edition. Lowa: WCB Brown \& Benchmark

Heppner, P. P., Pretorius, T. B., Wei, M., Lee, D.-G., \& Wang, Y. W. (2002). Examining the generalizability of problem solving appraisal in black South Africans. Journal of Counseling Psychology, 49, 484-498.

Kartono, K., \& Gulo, D. (2002). Kamus psikologi. Bandung: Pionir Jaya

Kirkpatrick, D. L (2006). Evaluating training programs. $\left(2^{\text {nd }} \mathrm{ed}\right)$. San Fransisco:Berrett-Kohler Publishers, Inc 
Kumar, R. (2005). Research methodology second edition: A step by step guide for beginners. London: Sage Publications Ltd

Latipun. (2006). Psikologi eksperimen. Malang: PT.UMM Press

Mosca, J.B., Farrari, A., \& Buzza, J. (2010). Coaching to win: A systemic approach to achieving productivity through coaching. Journal of Business \& Economic Research, 8(5), 115-130

Schermerhorn, J.R., Hunt, G.J., Osborn, R.N., \& Uhl-Bien, M. (2010). Organization behavior. $11^{\text {th }}$ edition. New Jersey: John Wiley \& Sons, Inc.

Shadish, W.R., Cook, T.D, \& Campbell, D.T. (2002). Experimental and quasi-eperimental design for generalized causal inference. New York: Houghton Mifflin Company.
Stein, S.J, \& Book, H.E. (2004). Ledakan EQ: 15 prinsip dasar kecerdasan emosional meraih sukses. Bandung: Kaifa

Sternberg, R. J. (2008). Psikologi kognitif. (Yudi Santoso, Penerjemah). Yogyakarta: Pustaka Pelajar

Thorne, K. (2005). Coaching for change: Peran pelatih dalam perubahan manusia dan organisasi. (Fiyanti Osman, Penerjemah). Jakarta : PT. Bhuana Ilmu Populer

Whitmore, J. (2009). Coaching for performance $4^{\text {rd }}$ ed. London: Nicholas Brealey

Wilson, C. (2011). Performance coaching, Metode baru mendongkrak kinerja karyawan. Jakarta: PPM Manajemen. 